\title{
Mapping Micro, Small And Medium Enterprises In The Gresik And Bawean Coastal Area
}

\author{
Tri Ratnawati ${ }^{1}$, I Nyoman Lokajaya ${ }^{2}$, Adelia Putri Rachmadani ${ }^{3}$, Nanda Oktaviyanto ${ }^{4}$ \\ Economics and Business Faculty, 17 August 1945 Surabaya University \\ Engineering Faculty, 17 August 1945 Surabaya University \\ DOI: 10.29322/IJSRP.11.10.2021.p11849 \\ http://dx.doi.org/10.29322/IJSRP.11.10.2021.p11849
}

\begin{abstract}
The coastal area of Gresik Regency which includes Ujungpangkah, Sangkapura, Sidayu, Manyar, Tambak, Bungah, Gresik, Panceng, and Kebomas has the potential for marine natural resources, business fields include manufacturing, trade and services, the main manufacturing industry producing food products made from fish, snacks, beverages, skullcap production. The purpose of this study was to map MSMEs in the coastal area of Gresik Regency. The benefit of the MSME mapping is that it makes it easier for academics to conduct research and assistance to focus on each type of industry and become a reference for the government to take policies and regulations related to the potential of MSMEs in each sub-district. The mapping method used is the GPS-based GIS method and the analysis uses the Pareto method. The results show that Manyar District has 613 MSMEs, Kebomas District has 567 MSMEs, Bungah District has 539 MSMEs, Gresik District has 518 MSMEs, Sidayu District has 484 MSMEs, District Sangkapura has 272 MSMEs, Ujungpangkah District has 170 MSMEs, Panceng District has 72 MSMEs.
\end{abstract}

Index Terms- Sub-district potential, industry, business legality

\section{INTRODUCTION}

Gresik Regency is a hinterland of the Surabaya metropolitan city so that it can be a buffer for the primary needs of the city of Surabaya. This potential makes Gresik Regency must continue to develop the manufacturing, trade and service business sectors. GeoChartically, Gresik Regency is surrounded by coastal areas which include Sidayu, Manyar, Bungah, UjungPangkah, Sangkapura, Kebomas, Tambak, Panceng, and Gresik sub-districts.

Based on data from the relevant agencies that: MSME mapping was carried out by sampling in Ujungpangkah and Sangkapura Districts, while for the other 6 sub-districts MSME mapping had not been carried out.

\section{Formulation of the Problem}

The problem is that there is no mapping of MSMEs in the coastal area of Gresik Regency.

\section{Research Purposes}

Produce information related to dominant business sectors, potential industries, business legality and sub-districts that excel in terms of MSME potential.

\section{Benefits of research}

1. For academics, especially researchers as a road map for research and service activities.

2. For the government, as a reference for the MSME database and provide recommendations for the resulting mapping.

3. For MSMEs as part of the promotion of their business fields.

4. For Corporate companies for CSR programs. 


\section{PREDECESSOR THEORY}

A. GIS theory with GPS

GeoChartic Information System (GIS) is basically a combination of three main elements, namely systems, information, and geoCharty.

GIS is an information system about places located on the earth's surface, knowledge of the position where an object is located on the earth's surface, and information about information (attributes) contained on the earth's surface whose position is given or known (Christanto and Susanto, 2013)

1. Pareto Theory

Pareto diagram is a diagram that explains that in each population there are some things that are more important than others.

Pareto diagrams can be used by everyone in everyday life, their organizations, and other community groups.

In general, the Pareto diagram is an observation made on many variables in everyday life that are not evenly distributed.

\section{MAPPING METHOD}

1. A survey was conducted to the agency related to the Gresik Regency's Department of Trade and Industry.

2. Survey to selected locations in Ujungpangkah area.

3. Created tabulation of data with excel.

4. A map of each coastal district was made.

5. Generated information related to the results of the mapping.

6. Provide recommendations to relevant government and academic parties as well as private parties for CSR programs.

\section{MAPPING RESULTS OF COASTAL MSMES IN GRESIK REGENCY}

A. Number of SMEs in Each District 


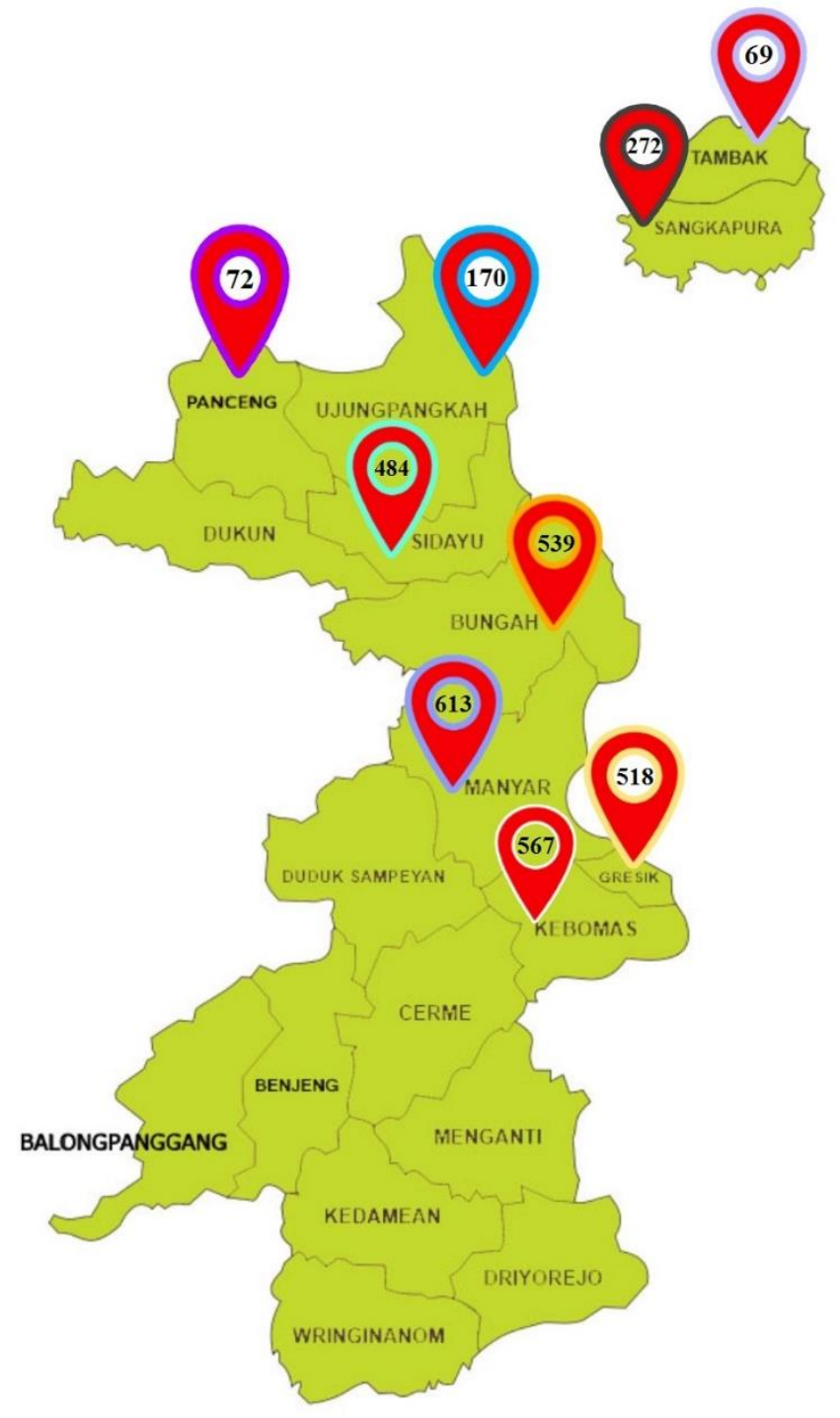

Based on the data obtained, the number of MSMEs on the coast of Gresik Regency, there are 3304 MSMEs spread in every nine sub-districts consisting of Manyar, Kebomas, Bungah, Gresik, Sidayu, Sangkapura, Ujungpangkah, Panceng, and Tambak sub-districts. This shows that Gresik district has good potential. These conditions are shown in the table. 1 which explains that the Manyar sub-district is the first biggest potential in Gresik district because the number of MSMEs reaches 613 MSMEs, the second is Kebomas sub-district with 567 MSMEs, the third is Bungah sub-district with 539 MSMEs, the fourth is Gresik sub-district with as many as 567 MSMEs. 518 MSMEs, the fifth is Sidayu sub-district with a total of 484 MSMEs, the sixth is Sangkapura sub-district with 272 MSMEs,

However, there are two sub-districts that still do not show good potential, because the number of MSMEs in Panceng sub-district is 72 MSMEs and Tambak sub-district is 69 MSMEs. So to increase and develop the potential in Gresik district to be even better, it is necessary to hold counseling and training in each sub-district to increase the enthusiasm of the community in building, improving, and developing MSMEs, especially for Panceng and Tambak sub-districts.

The Gresik Coastal Area covers the area of which is administratively located in the coastal district around Gresik Regency.

The demographics of Gresik Regency are as follows: 


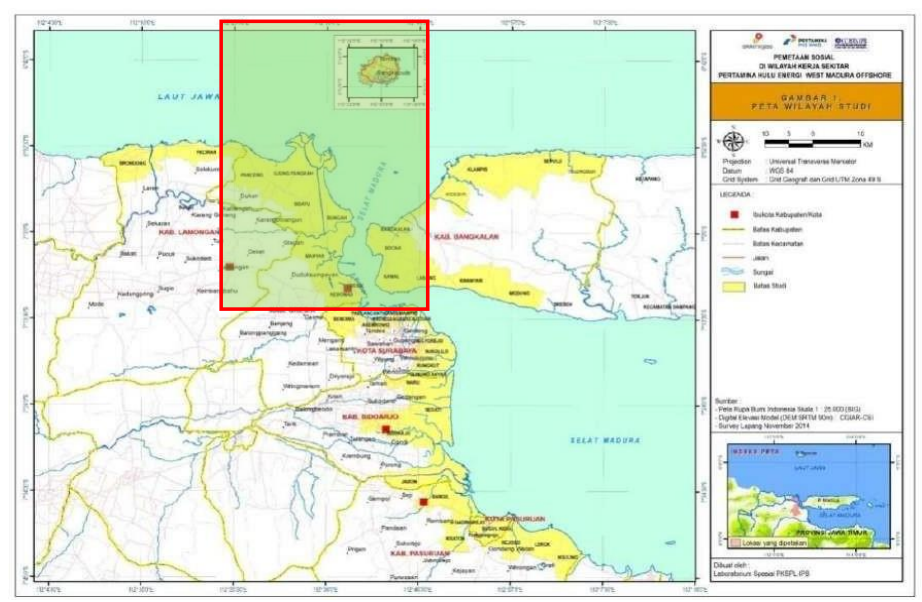

Figure 1. Gresik Regency Coastal Area Map

Results of the analysis using the Pareto diagram in Figure 2. it was found that $80 \%$ of the types of MSME manufacturing businesses in the coastal area of Gresik Regency were in Sidayu, Kebomas, Manyar, Gresik and Bungah Districts. While 20\% of the number of MSMEs are in Sangkapura, Ujungpangkah, Panceng and Tambak sub-districts.

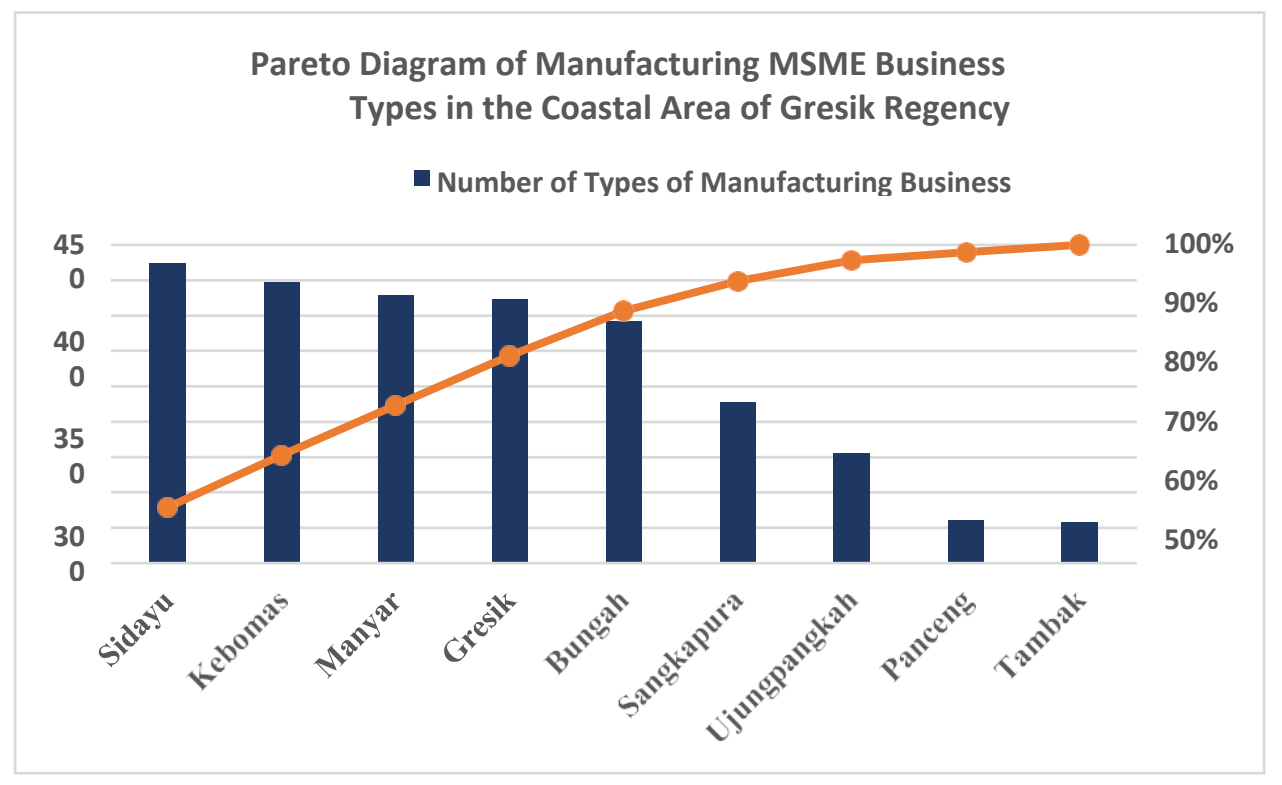

Source: Identification result

Figure 2. Pareto Chart Number of Types of Manufacturing MSME Businesses in the Coastal Area of Gresik Regency

The results of the analysis using the Pareto diagram in Figure 3 show that $80 \%$ of the types of MSME trading businesses in the coastal area of Gresik Regency are in the Districts of Gresik, Kebomas, Manyar and Sidayu. Meanwhile, $20 \%$ of the number of SMEs are in Sangkapura, Bungah, Tambak, Panceng and Ujungpangkah sub-districts. 


\section{Pareto Diagram Number of Types of Trading MSME \\ Businesses in the Coastal Area of Gresik Regency}

Nımhar af Tunec of Tradino Rucinecs

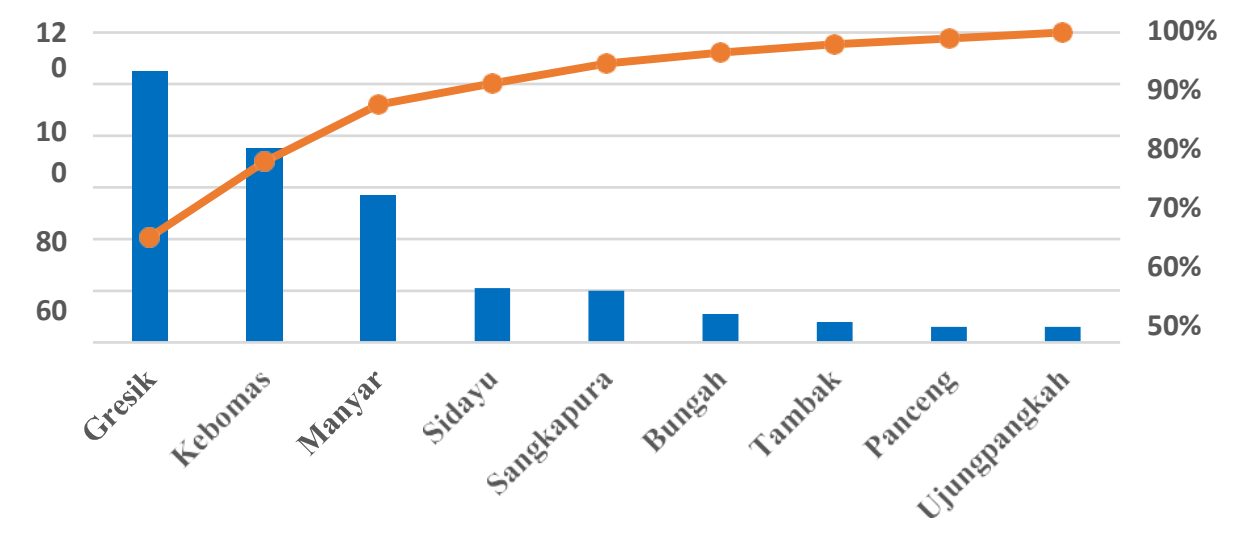

Source: Identification result

Figure 3. Pareto Diagram Number of Types of Trading MSME Businesses in the Coastal Area of Gresik Regency

The results of the analysis using the Pareto diagram in Figure 4 show that $80 \%$ of the types of MSME service businesses in the coastal area of Gresik Regency are in Bungah, Manyar and Kebomas Districts. Meanwhile, 20\% of the number of MSMEs are in Gresik, Sidayu, Sangkapura, Ujungpangkah, Panceng and Tambak sub-districts.

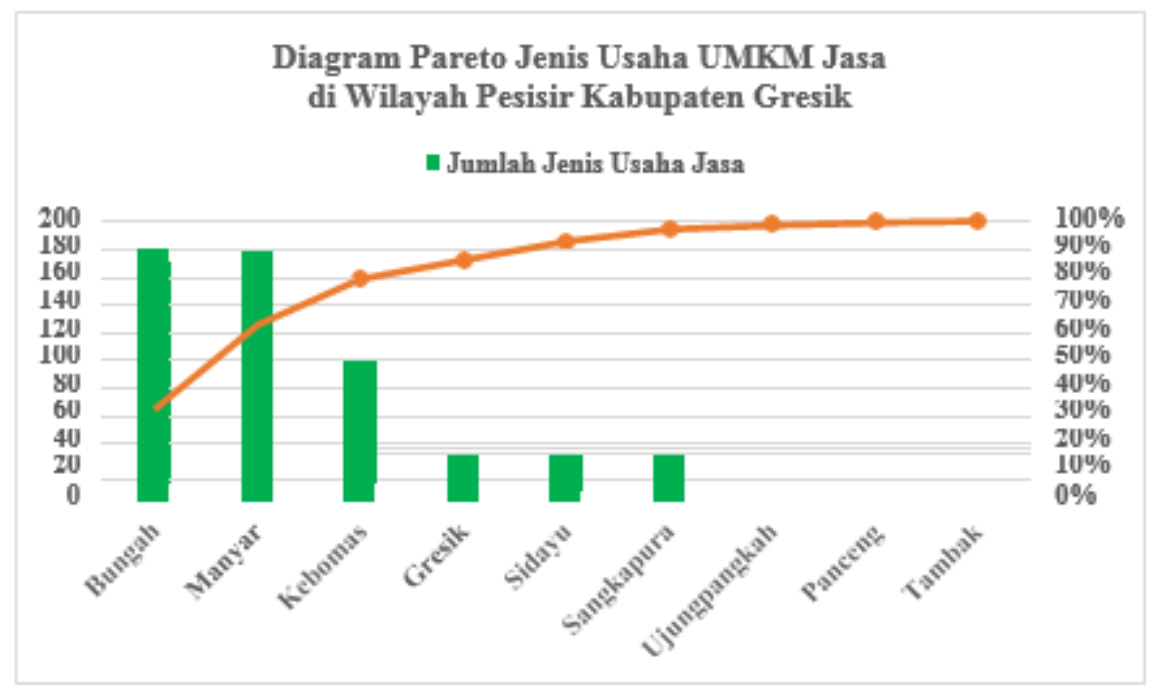

Source: Identification result

Figure 4. Pareto Chart Number of Types of Small and Medium Enterprises Services in the Coastal Area of Gresik Regency 
Table 1. Number of MSMEs in Each District

\begin{tabular}{|c|l|c|c|}
\hline No. & \multicolumn{1}{|c|}{ DISTRICTS } & NUMBER OF MSME & PERCENTAGE \\
\hline 1. & Manyar & 613 & $\mathbf{1 8 . 5 5 \%}$ \\
\hline 2. & Kebomas & 567 & $\mathbf{1 7 . 1 6 \%}$ \\
\hline 3. & Flower & 539 & $\mathbf{1 6 . 3 1 \%}$ \\
\hline 4. & Gresik & 518 & $\mathbf{1 5 . 6 8 \%}$ \\
\hline 5. & Sidayu & 484 & $\mathbf{1 4 . 6 5 \%}$ \\
\hline 6. & Sangkapura & 272 & $\mathbf{2 . 1 8 \%}$ \\
\hline 7. & Ujungpangkah & 170 & $\mathbf{5 . 1 5 \%}$ \\
\hline 8. & Panceng & 72 & $\mathbf{8 . 2 3 \%}$ \\
\hline 9. & Tambak & 69 & $\mathbf{2 . 0 9 \%}$ \\
\hline & \multicolumn{2}{|c|}{ AMOUNT } &
\end{tabular}

B. Number of Industries of Each Sector of Each District

The industrial sector in each sub-district of Gresik Regency is divided into 3 sectors, namely the manufacturing, trade, and service industries. Based on the data in Table 2. and Chart 1. in each sub-district in Gresik district, the coastal area includes the districts of Manyar, Kebomas, Bungah, Gresik, Sidayu, Sangkapura, Ujungpangkah, Panceng, and Tambak. The industrial sector of each sub-district in the coastal area of Gresik Regency is dominated by the manufacturing industry sector with a total of 2,416 MSMEs, then services with a total of 579 MSMEs, and the smallest industrial sector, namely trade with a total of 309 MSMEs.

Table 2. Types of MSME Business

\begin{tabular}{|l|l|r|r|r|r|}
\hline No & Districts & Manufacture & Trading & Service & Amount \\
\hline 1. & Manyar & 379 & 57 & 177 & 613 \\
\hline 2. & Kebomas & 397 & 75 & 95 & 567 \\
\hline 3. & Bungah & 342 & 11 & 186 & 539 \\
\hline 4. & Gresik & 373 & 105 & 40 & 518 \\
\hline 5. & Sidayu & 424 & 21 & 39 & 484 \\
\hline 6. & Panceng & 61 & 6 & 5 & 72 \\
\hline 7. & Ujungpangkah & 155 & 6 & 9 & 170 \\
\hline 8. & Sangkapura & 227 & 20 & 25 & 272 \\
\hline 9. & Tambak & 58 & 8 & 3 & 69 \\
\hline & & 2.416 & 309 & 579 & 3.304 \\
\hline
\end{tabular}

Chart 1. Type of MSME Business

Grafik Jumlah Jenis Usaha UMKM

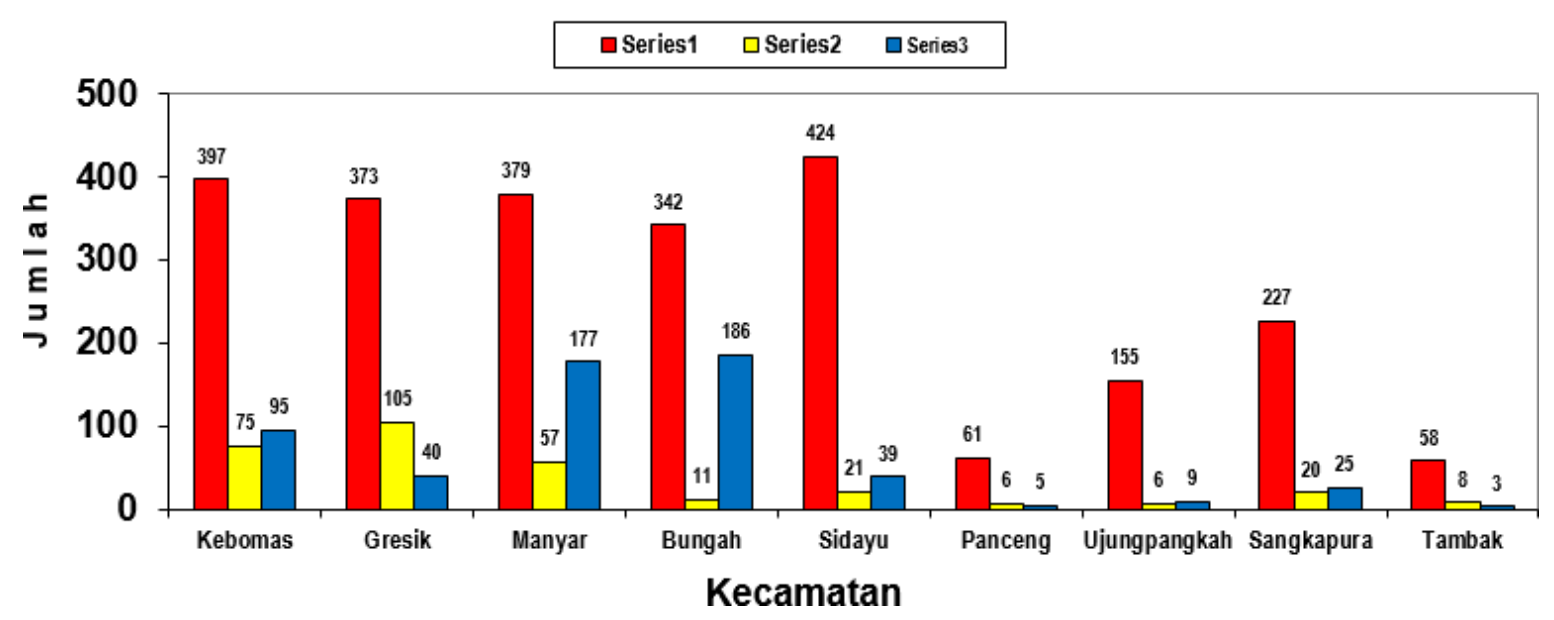


While in Table 3. and Chart 2. about the types of industrial businesses in the coastal area of Gresik Regency. The most common type of MSME industry business out of all is the type of manufacturing industry business with a total of 84 MSMEs consisting of the 12 most types of manufacturing industry business and found in Manyar and Bungah Districts. Then followed by the type of trade and service industry business with the same total, namely 50 MSMEs engaged in the industry. However, the number of types is different, based on the data obtained that Kebomas District is the largest type of trading business and Manyar District has the largest number of service business types with 13 types and 10 types of industry respectively.

Table 3. Types of Industrial Business

\begin{tabular}{|c|c|c|c|c|c|}
\hline No & Districts & Manufacture & Trading & Service & Amount \\
\hline 1. & Manyar & 12 & 7 & 10 & 29 \\
\hline 2. & Kebomas & 9 & 13 & 9 & 31 \\
\hline 3. & Bungah & 12 & 9 & 6 & 27 \\
\hline 4. & Gresik & 9 & 7 & 8 & 24 \\
\hline 5. & Sidayu & 9 & 3 & 5 & 17 \\
\hline 6. & Panceng & 7 & 3 & 4 & 14 \\
\hline 7. & Ujungpangkah & 9 & 1 & 4 & 14 \\
\hline 8. & Sangkapura & 10 & 4 & 2 & 16 \\
\hline 9. & Tambak & 7 & 3 & 2 & 12 \\
\hline & & 84 & 50 & 50 & 184 \\
\hline
\end{tabular}

Chart 2. Types of Industrial Business

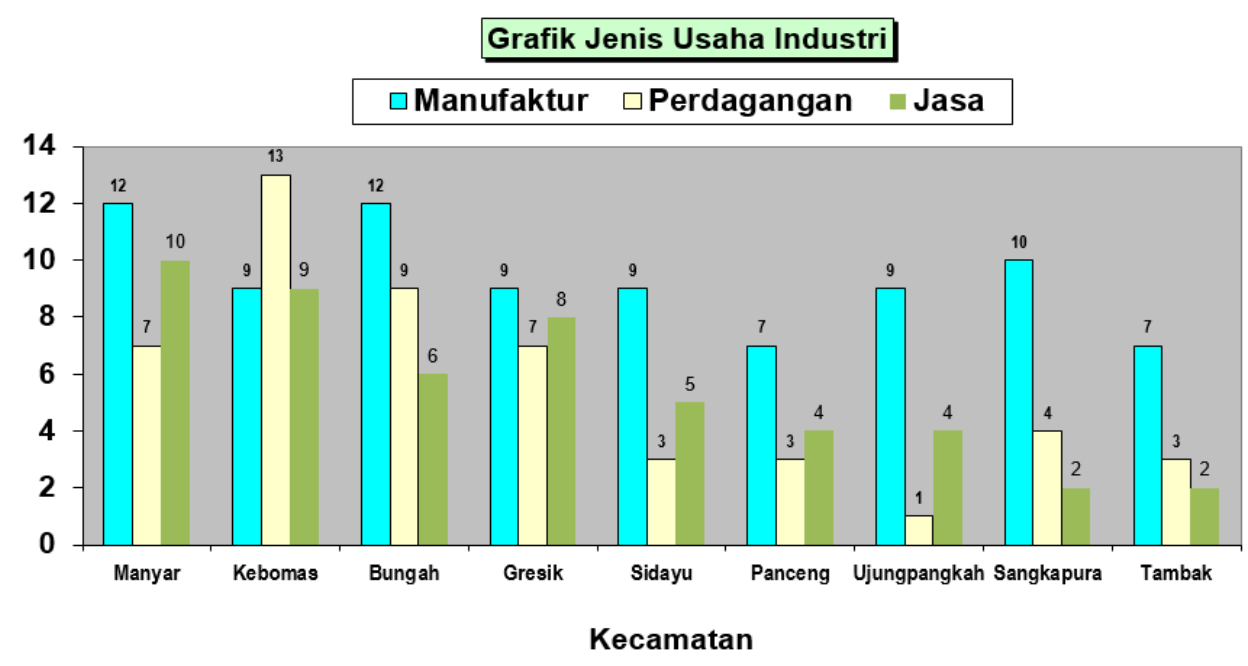

C. Business Legality of Each District

The government focuses more on MSMEs in every sub-district of the coastal area of Gresik Regency, because as many as 2,596 MSMEs in this region do not yet have legality, it is also explained based on the percentage of $78.57 \%$ with the largest percentage of sub-districts that do not have legality, namely Bungah, Gresik, Manyar, and Sidayu with their respective amounts of $15.65 \%, 13.41 \%, 13.11 \%$, and $13.08 \%$. However, the number of MSMEs that have legality is 708 MSMEs consisting of Kebomas District, which amounts to 334 MSMEs with a total percentage of $10.11 \%$. This statement is supported based on data processing in Table 8. and Chart 3. regarding business legality. The importance of legality for MSMEs really helps MSMEs in various fields.

1. MSMEs get guaranteed legal protection

2. Facilitate business development

3. Facilitate business marketing

4. Easier access to financing

5. Obtain business assistance from the government. 
MSMEs need convenience in obtaining business capital loans, while in the condition of MSMEs in the Gresik Coastal Region, the lack of MSMEs that have legality is a major concern. Many MSME actors complain about the difficulties in managing the legality of their business, so it is necessary for MSME actors to take care of legality. The government should play an important role in providing facilities so that later they can develop MSMEs in the Gresik Coastal Area.

Table 4. Business Legality of Each District

\begin{tabular}{|l|l|r|r|r|r|r|r|r|r|r|r|}
\hline No & \multicolumn{1}{|c|}{ districts } & PT & CV & UD & PD & PO & $\begin{array}{c}\text { Percentage } \\
\text { is not } \\
\text { any }\end{array}$ & Amount & $\begin{array}{r}\text { No } \\
\text { There is } \\
\text { Legality }\end{array}$ & $\begin{array}{r}\text { Amount } \\
\text { There is } \\
\text { Legality }\end{array}$ & $\begin{array}{c}\text { Percentage } \\
\text { There is } \\
\text { Legality }\end{array}$ \\
\hline 1. & Manyar & 151 & 13 & 16 & 0 & 0 & 433 & 613 & $13.11 \%$ & 180 & $5.45 \%$ \\
\hline 2. & Kebomas & 256 & 47 & 25 & 3 & 3 & 233 & 567 & $7.05 \%$ & 334 & $10.11 \%$ \\
\hline 3. & Bungah & 4 & 6 & 12 & 0 & 0 & 517 & 539 & $15.65 \%$ & 22 & $0.67 \%$ \\
\hline 4. & Gresik & 50 & 8 & 17 & 0 & 0 & 443 & 518 & $13.41 \%$ & 75 & $2.27 \%$ \\
\hline 5. & Sidayu & 22 & 16 & 14 & 0 & 0 & 432 & 484 & $13.08 \%$ & 52 & $1.57 \%$ \\
\hline 6. & Panceng & 17 & 4 & 1 & 0 & 0 & 50 & 72 & $1.51 \%$ & 22 & $0.67 \%$ \\
\hline 7. & Ujungpangkah & 8 & 0 & 9 & 0 & 0 & 153 & 170 & $4.63 \%$ & 17 & $0.51 \%$ \\
\hline 8. & Sangkapura & 2 & 3 & 0 & 0 & 0 & 267 & 272 & $8.08 \%$ & 5 & $0.15 \%$ \\
\hline 9. & Tambak & 1 & 0 & 0 & 0 & 0 & 68 & 69 & $2.06 \%$ & 1 & $0.03 \%$ \\
\hline & & $\mathbf{5 1 1}$ & $\mathbf{9 7}$ & $\mathbf{9 4}$ & $\mathbf{3}$ & $\mathbf{3}$ & $\mathbf{2 5 9}$ & $\mathbf{3 . 3 0 4}$ & $\mathbf{7 8 . 5 7 \%}$ & $\mathbf{7 0 8}$ & $\mathbf{2 1 . 4 3 \%}$ \\
\hline
\end{tabular}

Chart 3. Percentage of Legality

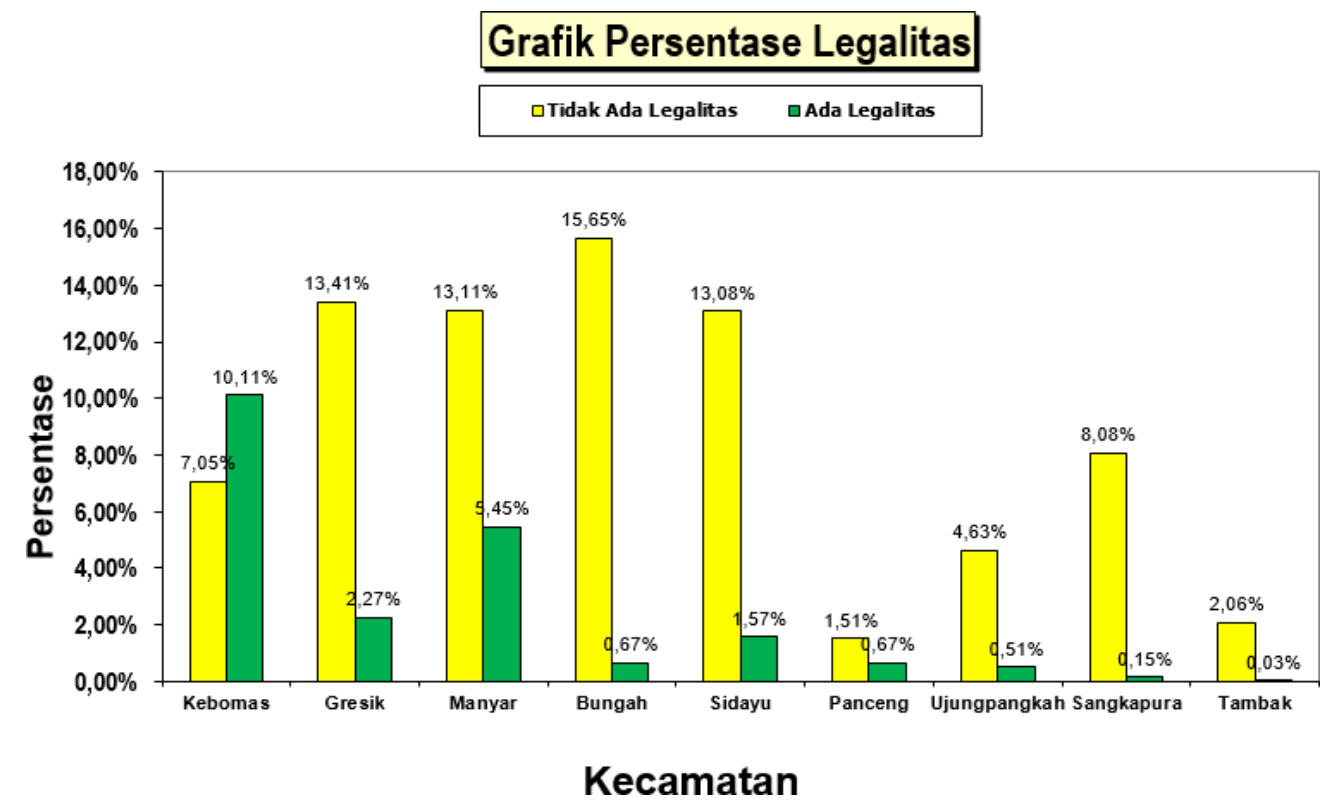


D. Ranking the Potential of MSMEs in the Manufacturing Sector of Each District

The coastal area of Gresik district has MSMEs engaged in the manufacturing sector with the largest number of which is 2,416 MSMEs and the number of industries is 12 types of manufacturing industry with a total number of manufacturing industrial sectors from all sub-districts in the coastal area of Gresik district amounting to 84. Based on the ranking results that have been in arranged in Table 5. Sidayu sub-district is the main one with 424 MSMEs. Then followed by 6 other sub-districts which include Kebomas, Manyar, Gresik, Bungah, Sangkapura, and Ujungpangkah sub-districts with the number of MSMEs above 100 MSMEs. Meanwhile, Panceng and Tambak sub-districts are the smallest contributors to the manufacturing sector, namely the number of MSMEs under 100 with the number of MSMEs in Panceng sub-district 61 MSMEs and Tambak 58 MSMEs.

Table 5. Ranking of Potential MSMEs in the Manufacturing Sector in Each District

\begin{tabular}{|l|l|l|r|r|}
\hline NO. & \multicolumn{1}{|c|}{ DISTRICTS } & \multicolumn{1}{c|}{ SECTOR } & $\begin{array}{c}\text { AMOUNT } \\
\text { INDUSTRY }\end{array}$ & $\begin{array}{c}\text { NUMBER OF } \\
\text { MSME }\end{array}$ \\
\hline 1. & Sidayu & Manufacture & 9 & 424 \\
\hline 2. & Kebomas & Manufacture & 9 & 397 \\
\hline 3. & Manyar & Manufacture & 12 & 379 \\
\hline 4. & Gresik & Manufacture & 12 & 373 \\
\hline 5. & Bungah & Manufacture & 10 & 342 \\
\hline 6. & Sangkapura & Manufacture & 9 & 227 \\
\hline 7. & Ujungpangkah & Manufacture & 7 & 155 \\
\hline 8. & Panceng & Manufacture & 7 & 61 \\
\hline 9. & Tambak & Manufacture & $\mathbf{8 4}$ & 58 \\
\hline & \multicolumn{2}{|c|}{ AMOUNT } & $\mathbf{2 4 1 6}$ \\
\hline
\end{tabular}

\section{E. Ranking the Potential of MSMEs in the Trade Sector in Each District}

The coastal area of Gresik district has MSMEs engaged in the trade sector with the smallest number compared to the manufacturing and service sectors, which are 309 MSMEs and the number of industries is 13 types of trade with a total number of trading industrial sectors from all sub-districts in the coastal area of Gresik district amounting to 50. Based on the ranking results that have been compiled in Table 6. Gresik sub-district is the main one with 105 MSMEs. Then followed by 5 other sub-districts which include Kebomas, Manyar, Sidayu, Sangkapura, and Bungah sub-districts with the number of MSMEs above 10 MSMEs. Meanwhile, the sub-districts of Tambak, Ujungpangkah, and Panceng are the smallest contributors to the trade sector, namely the number of MSMEs under 10 with the number of MSMEs in the Tambak sub-district 8 MSMEs, Ujungpangkah 6 MSMEs and Panceng 6 MSMEs.

Table 6. Ranking of Potential SMEs in the Trade Sector in Each District

\begin{tabular}{|l|l|l|r|r|}
\hline NO. & \multicolumn{1}{|c|}{ DISTRICTS } & \multicolumn{1}{c|}{$\begin{array}{c}\text { AMECTOR } \\
\text { INDUSTRY }\end{array}$} & $\begin{array}{c}\text { NUMBER } \\
\text { OF MSME }\end{array}$ \\
\hline 1. & Gresik & Trading & 7 & 105 \\
\hline 2. & Kebomas & Trading & 13 & 75 \\
\hline 3. & Manyar & Trading & 9 & 57 \\
\hline 4. & Sidayu & Trading & 7 & 21 \\
\hline 5. & Sangkapura & Trading & 3 & 20 \\
\hline 6. & Bungah & Trading & 3 & 11 \\
\hline 7. & Tambak & Trading & 1 & 8 \\
\hline 8. & Ujungpangkah & Trading & 4 & 6 \\
\hline 9. & Panceng & Trading & 3 & 6 \\
\hline & \multicolumn{2}{|c|}{ AMOUNT } & $\mathbf{5 0}$ & $\mathbf{3 0 9}$ \\
\hline
\end{tabular}

\section{F. Ranking the Potential of MSMEs in the Service Sector in Each District}

The coastal area of Gresik district has MSMEs engaged in the service sector with the second largest number after the manufacturing industry sector, which is 579 MSMEs and the number of industries is 10 types of services with a total number of service sectors from all sub-districts in the coastal area of Gresik district amounting to 50. arranged in Table 7. Bungah subdistrict is the main one with 186 MSMEs. Then followed by 5 other sub-districts which include Manyar, Kebomas, Gresik, Sidayu, and Sangkapura sub-districts with the number of MSMEs above 10 MSMEs. Meanwhile, Ujungpangkah, Panceng, and 
Tambak sub-districts are the smallest contributors to the service sector, namely the number of MSMEs below 10 with the number of MSMEs in Ujungpangkah sub-district 9 MSMEs, Panceng 5 MSMEs, and Tambak 3 MSMEs.

Table 7. Ranking of Service Sector MSME Potentials in Each District

\begin{tabular}{|l|l|l|r|r|}
\hline NO. & \multicolumn{1}{|c|}{ DISTRICTS } & \multicolumn{1}{c|}{ SECTOR } & \multicolumn{1}{c|}{$\begin{array}{c}\text { AMOUNT } \\
\text { INDUSTRY }\end{array}$} & $\begin{array}{c}\text { NUMBER OF } \\
\text { MSME }\end{array}$ \\
\hline 1. & Bungah & Service & 6 & 186 \\
\hline 2. & Manyar & Service & 10 & 177 \\
\hline 3. & Kebomas & Service & 9 & 95 \\
\hline 4. & Gresik & Service & 8 & 40 \\
\hline 5. & Sidayu & Service & 5 & 39 \\
\hline 6. & Sangkapura & Service & 2 & 25 \\
\hline 7. & Ujungpangkah & Service & 4 & 9 \\
\hline 8. & Panceng & Service & 4 & 5 \\
\hline 9. & Tambak & Service & 2 & 3 \\
\hline & \multicolumn{2}{|c|}{ AMOUNT } & $\mathbf{5 0}$ & $\mathbf{5 7 9}$ \\
\hline
\end{tabular}

\section{G. Distribution of MSME Industry Types in the Coastal Area of Gresik Regency}

Based on the grouping of MSME data in Table 8. shows that the distribution of the types of MSME industries in the coastal area of Gresik Regency there are 40 types of industries which are divided into three industrial sectors, namely the manufacturing, trade and service industries. Each industrial sector of each existing MSME consists of 14 types of manufacturing industry, 14 types of trading industry, and 12 types of service industry.

The majority of the manufacturing industry sector is in the districts of Sidayu, Kebomas, Manyar, Gresik, and Sangkapura. The majority of industries are engaged in the processing of raw materials into semi-finished and finished materials, food, beverages, convection, weaving and handicrafts. Sidayu District is the largest and largest majority of the three types of industry, namely processing raw materials into semi-finished materials and finished materials totaling 189 MSMEs consisting of making fish crackers totaling 96 MSMEs, making kopyah materials totaling 46 MSMEs, making shrimp pastes totaling 25 MSMEs, and make fertilizers totaling 22 SMEs. Then the type of food industry is 134 MSMEs which consists of making snacks totaling 101 MSMEs, making cakes/breads totaling 28 MSMEs, and staple foods totaling 5 MSMEs and the last one is the type of processed industry totaling 66 MSMEs consisting of making preparations from pond and sea products. Kebomas sub-district is a manufacturing industry sector, the majority of which are beverages, with a total of 37 MSMEs. Manyar District is the manufacturing industry sector, the majority of which are the type of convection industry, totaling 97 MSMEs, consisting of 66 MSMEs veil/veil convection, 25 MSMEs for clothing, and 5 MSME skullcaps. Gresik sub-district is the manufacturing industry sector, the majority of which are the weaving industry, amounting to 75 MSMEs, consisting of weaving of skullcaps and sarongs.

The trading industry sector, the majority of which are engaged in trading accessories for school children such as bags, shoes, and clothing accessories, are located in Gresik District with a total of 83 MSMEs. Then, the service industry sector, the majority of which is in the field of sewing services, with the largest number in Bungah District with a total of 158 MSMEs. The sewing services consist of sewing services for kopyah materials, totaling 45 MSMEs, sewing clothes totaling 17 MSMEs, sewing headscarves/headscarf totaling 77 MSMEs, sewing skullcaps totaling 19 MSMEs.

Table 8. Types of Industry in each District

\begin{tabular}{|c|c|c|c|c|c|c|c|c|c|c|}
\hline \multirow[b]{2}{*}{ Industry Type } & \multicolumn{9}{|c|}{ Districts } & \multirow[b]{2}{*}{$\begin{array}{c}\text { AMOUN } \\
\quad \mathbf{T} \\
\end{array}$} \\
\hline & \begin{tabular}{|l} 
Manya \\
$\mathrm{r}$ \\
\end{tabular} & $\begin{array}{l}\text { Keboma } \\
\mathrm{s}\end{array}$ & $\begin{array}{l}\text { Bunga } \\
\mathrm{h}\end{array}$ & $\begin{array}{l}\text { Gresi } \\
\mathrm{k}\end{array}$ & $\begin{array}{l}\text { Siday } \\
\mathrm{u}\end{array}$ & $\begin{array}{l}\text { Sangkapur } \\
\text { a }\end{array}$ & $\begin{array}{l}\text { Ujungpangka } \\
\mathrm{h}\end{array}$ & $\begin{array}{l}\text { Pancen } \\
\mathrm{g}\end{array}$ & $\begin{array}{l}\text { Tamba } \\
\mathrm{k}\end{array}$ & \\
\hline $\begin{array}{l}\text { Processing } \\
\text { industry }\end{array}$ & 133 & 145 & 93 & 44 & 189 & 64 & 38 & 35 & 21 & 762 \\
\hline
\end{tabular}




\begin{tabular}{|c|c|c|c|c|c|c|c|c|c|c|}
\hline \begin{tabular}{l|l}
2. & Snack
\end{tabular} & 26 & 28 & 92 & 26 & 101 & 33 & 67 & 10 & 10 & 393 \\
\hline Tailor Service & 104 & - & 158 & 7 & 27 & - & - & - & - & 296 \\
\hline Convection & 97 & 11 & 80 & 77 & 11 & 1 & 2 & - & - & 279 \\
\hline Cake/Bread & 38 & 66 & 4 & 79 & 28 & 11 & 6 & 1 & 1 & 234 \\
\hline Furniture & 7 & 73 & 19 & 4 & 12 & 44 & 15 & 5 & 6 & 185 \\
\hline \begin{tabular}{l|l}
7. & Processed \\
\end{tabular} & 27 & 10 & 22 & 16 & 66 & 1 & 16 & 4 & 17 & 179 \\
\hline Service & 29 & 20 & 24 & 9 & 7 & 24 & - & - & 2 & 115 \\
\hline Drink & 26 & 37 & 4 & 29 & 10 & - & 4 & 3 & - & 113 \\
\hline \begin{tabular}{l|l}
10 & Accessories \\
\end{tabular} & 12 & 4 & - & 83 & - & - & - & - & - & 99 \\
\hline Craft & 14 & - & 1 & - & - & 67 & 5 & 2 & 2 & 91 \\
\hline Weaving & - & 1 & - & 75 & 2 & - & - & - & - & 78 \\
\hline Material & 11 & 14 & 9 & - & 10 & 17 & 1 & 4 & 8 & 74 \\
\hline \begin{tabular}{l|l}
14 & $\begin{array}{l}\text { Food } \\
\text { Tree }\end{array}$ \\
\end{tabular} & 4 & 26 & 2 & 23 & 5 & 2 & 2 & 3 & 1 & 68 \\
\hline \begin{tabular}{l|l}
15 & Property \\
\end{tabular} & 9 & 27 & 1 & 1 & 1 & - & - & - & - & 39 \\
\hline Installation & 6 & 24 & - & 5 & - & - & - & - & 1 & 36 \\
\hline $\begin{array}{ll}17 & \begin{array}{l}\text { Gasoline, Gas } \\
\text { and Oil }\end{array} \\
\end{array}$ & 16 & 8 & - & 5 & 3 & 1 & - & - & - & 33 \\
\hline \begin{tabular}{l|l}
18 & $\begin{array}{l}\text { Seasonings/Spic } \\
\text { es }\end{array}$ \\
\end{tabular} & 7 & 14 & 1 & 4 & - & - & - & - & - & 26 \\
\hline Service & 6 & 8 & - & 8 & - & - & 2 & 1 & - & 25 \\
\hline \begin{tabular}{l|l}
20 & $\begin{array}{l}\text { Construction } \\
\text { service }\end{array}$ \\
\end{tabular} & 12 & 4 & 1 & 1 & - & 1 & 3 & 1 & - & 23 \\
\hline \begin{tabular}{l|l}
21 & Musical \\
instrument
\end{tabular} & - & - & 22 & - & - & - & - & - & - & 22 \\
\hline Printing & - & 6 & - & 8 & 3 & - & 3 & 1 & - & 21 \\
\hline Trading & 3 & 3 & - & 7 & 3 & - & 3 & 1 & - & 20 \\
\hline \begin{tabular}{l|l}
24 & Production \\
Equipment
\end{tabular} & 3 & 5 & - & 3 & 2 & - & - & - & - & 13 \\
\hline Health & 5 & 3 & 1 & 1 & 1 & - & 1 & - & - & 12 \\
\hline \begin{tabular}{|l|l}
26 & $\begin{array}{l}\text { Household } \\
\text { appliance }\end{array}$ \\
\end{tabular} & 1 & 5 & - & - & 1 & 2 & 1 & 1 & - & 11 \\
\hline Parts & - & 9 & - & 1 & - & - & - & - & - & 10 \\
\hline Aquatic Results & 2 & 2 & 1 & 2 & 1 & - & 1 & - & - & 9 \\
\hline Quarry Industry & 3 & - & 2 & - & - & 3 & - & - & - & 8 \\
\hline $\begin{array}{l}\text { Machinery } \\
\text { Industry }\end{array}$ & 3 & - & 1 & - & - & 1 & - & - & - & 5 \\
\hline Showroom & 2 & 3 & - & - & - & - & - & - & - & 5 \\
\hline Designing & - & 4 & - & - & - & - & - & - & - & 4 \\
\hline Restaurant & 3 & - & 1 & - & - & - & - & - & - & 4 \\
\hline
\end{tabular}


3. The market reach is a synergy program between Regional Governments throughout East Java in terms of defeating the marketing of MSME products and even expanding the market reach at the National and International levels.

4. Academics provide intensive assistance in terms of the use of marketing technology ranging from promotions to online sales and payments using Financial Technology.

5. Academics can synergize with large-scale companies in the Gresik Regency (PT. Semen Indonesia Tbk, PT. Petrokimia Gresik, PT. Smelting, etc.) in terms of providing assistance in the procurement of production equipment so that Appropriate Technology (TTG) is achieved through mentoring / coaching in terms of the use of tools carried out by academics.

6. Assistance by academics in terms of Digitalization of Simple Accounting by implementing the applicable SAK EMKM which can be done with a smartphone so that MSMEs can compile Financial Reports on time.

\section{REFERENCES}

Anoraga, Pandji and H. Djoko Sudantoko, 2002, Entrepreneurship and Business Cooperatives Small,PT. Rineka Cipta, Jakarta.

Christanto, Febrian Wahyu and Susanto. 2013. Mapping of Tourism Object Facilities and Infrastructure in Semarang Regency, Central Java Using GeoChartic Information Systems. Journal of Transformatics, Volume 10, No.2, January 2013:5-62

Judge, Moh. Taufiqul. 2017. Determination of the Location Criteria for Small Fishery Industries in Gresik Regency. Department of Urban and Regional Planning, Faculty of Civil Engineering and Planning, Sepuluh Nopember Institute of Technology Surabaya

Pressman, RS 1997. Software Engineering: A Practitioner's Approach. The McGraw-Hill Companies Inc, New York

Ratnawati, H. T., Rohmasari, F., \& Lokajaya, I. N. (2017). Financial Literacy And Financial Inclusion Strategy Model As Leverage Welfare Of Industrial Community Tourism Regency Of Gresik East Java. Archives of Business Research, 5(9), 151-163. https://doi.org/10.14738/abr.59.3718

Teknik, F. (2020). PKM TEKNOLOGI TEPAT GUNA. 1(1), 99-110.

https://gresikkab.bps.go.id/statictable/2020/02/28/99/pdrb-kabupaten-gresik-atas-dasar-hargamillion-rupiah-2013-2019.html apply-by-field-business-

\section{AUTHORS}

First Author : $\quad$ Tri Ratnawati, Economics and Business Faculty, 17 August 1945 Surabaya University, triratnawati@untagsby.ac.id

Second Author : I Nyoman Lokajaya, Engineering Faculty, 17 August 1945 Surabaya University, lokajaya@untag-sby.ac.id

Third Author: $\quad$ Adelia Putri Rachmadani, Economics and Business Faculty, 17 August 1945 Surabaya University, adeliaputrir.ap@gmail.com

Fourth Author : Nanda Oktaviyanto, Economics and Business Faculty, 17 August 1945 Surabaya University, nandaoktafiyanto03@gmail.com

Correspondence Author Adelia Putri Rachmadani, triratnawati@untag-sby.ac.id, adeliaputrir.ap@gmail.com, 0895 - 2984 0228 